\title{
Os recursos do discurso (Alejo Carpentier e Descartes) JÚLIO CÉSAR LOBO jornalista.
}

A parte 8 do $3^{\circ}$ capítulo do romance $O$ Recurso do Método, de Alejo Carpentier, comȩ̧a com uma epígrafe, tida como de René Descartes: "É melhor modificar os nossos desejos do que a ordem do mundo..." (1974, p. 109). Acontece que essa epigrafe - bem como algumas outras espalhadas pelo texto - não é do autor de Regras para a Direção do Espiritto (1620-35) nem tampouco uma trađução livre do filósofo, matemático e físico, mas sim uma adaptação interesseira, uma paráfrase, ou melhor, uma deturpação do seu pensamento. Descartes jamais disse que "é melhor modificar nossos desejos do que a ordem do mundo" . A consulta ao Discurso sobre o Método, em busca da origem da idéia, revelará uma outra construção: " 1 minha terceira máxima estava em buscar sempre vencer primeiro a mim do que a fortuna, $\mathrm{em}$ modificar antes os meus desejos do que a ordem do mundo e, de um modo geral, em acostumar-me a acreditar que nada há que esteja tâo inteiramente $\mathrm{cm}$ nosso poder como os nossos pensamentos, de modo que, após fazermos tudo quanto esteja dentro de nossas possibilidades no que tange às coisas que nos sảo exteriores. todo o restante que não alcançamos, a nosso respeito, é absolutamente impossivel".

Um pouco antes da paráfrase da "Terceira Máxima", há, no texto de Carpentier, uma outra "epigrafe de Descartes", abrindo o $2^{\circ}$ capitulo: " ... tão teimosamente está cada um com seu critério que poderíamos achar tantos reformadores quantas cabeças houvesse..." (p. 33). No Discurso sobre o Método, $6^{2}$ parte, o período 6 o seguinte: " (...) no que tange aos costumes, as opiniōes são em tẫo grande número que seria possivel achar tantos reformadores quantas são as cabeças, se a outros, que não aqueles que Deus designou como soberanos dos seus povos ou aqueles a quem concedeu tanta graça e zelo para se fazerem profetas, fosse dado inovar alguma coisa nesse campo...". As paráfrases vão se seguindo e, na maioria dos casos, o resultado é de bom humor: "Vejo, logo sou" (p. 263).

$O$ romance $O$ Recurso do Mótodo tem um narrador que não se confunde com o autor. Em alguns momentos, há até uma troca de narrador para que o principal o Primeiro Magistrado, também chamado de Presidente e Mandatário -, ditador de uma banana republic não-identificada (" $l a a^{\prime \prime}$ ), possa dialogar, por exemplo. Assim, se o narrador é, na verdade, o Primeiro Magistrado (ou seria o PM um alter ego do narrador?), se é ele quem " escreve" o que estamos lendo, as epígrafes sảo tambem de sua lavra. Deste modo, poderiam ser explicadas as paráfrases, as deturpações de um pensamento, tido como uma das referências do racionalismo ocidental, apenas para se encaixar em uma determinada ideologia, associada ao autoritarismo.

No universo de leituras (?) do Primeiro Magistrado, Descartes dissera aquelas

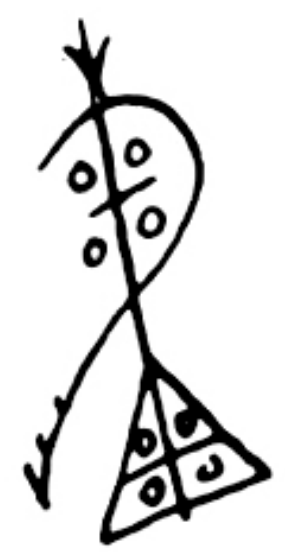


frases daquela maneira, com aquela redação. No entanto, a escrita das epigrafes do narrador-PM trai, no mínimo, um desejo forte de deturpaçâo, um dolo, que acaba espelhando um falso conhecimento aprofundado das obras do mestre francês. As citações do Primeiro Magistrado e do co-narrador e a série interminável de referências ("... a dividir cartesianamente o conjunto em partes cuja multiplicidade....", p. 295) revelam como que um procedimento de alguém que tivesse lido, por exemplo, uma seleção de citações de um determinado pensador, tivesse memorizado as mais freqüentes e passasse a citá-las de ouvido, deturpadas, adaptadas às conveniências.

Um scbolar muito rigoroso poderia até indagar, com os recursos do seu método, sobre o que poderia haver de interessante $\mathrm{cm}$ se levantar, mesmo que alcatoriamente, as origens das epigrafes de um romance, uma obra de fiç̧ão, mesmo que esse romance, como no caso de O Recurso do Método, tenha exatas dezenove epigrafes de um mesmo autor - " Descartes". Isto poderia ser levantado se o narrador não fosse um homem dividido entre dois mundos. Melhor, se o narrador, o Primeiro Magistrado, não fosse um ditador, metido a ilustrado, que somente se sente bem $\mathrm{em}$ Paris e não em sua republiqueta ao sul do Rio Grande, onde se dá diariamente, desde os tempos de Cristóvão Colombo e Cortez, o real horroroso americano.

Assim, as epigrafes - e o romance abusa delas - funcionam não como a tradução de uma genuína ilustração, mas sim, na maioria dos casos, como a impostura de uma dissimulação, refletindo uma pseudoerudição, por sinal, glosada por Alejo Carpentier, em um trecho do bem-humorado A Harpa e a Sombra.

$$
\begin{aligned}
& \text { " - Quem rouba o pão do suor alheio é como aquele que mata scu pró- } \\
& \text { ximo, clama, terrivel, Frei Bartolomeu de las Casas. } \\
& \text { - Quem está citando Marx? - pergunta o Protonotário, abruptamente } \\
& \text { arrancado de um profundo sono. } \\
& \text { - Capítulo } 34 \text { do Eclesiastes - esclarece o bispo de Chiapas... } \\
& \text { - Deixemos isso e passemos à questão de moralidade do Postulado - diz } \\
& \text { o Presidente" (1979, p. 165). }
\end{aligned}
$$

O Primeiro Magistrado, de O Recurso do Método, trai assim, com as suas citaçốesepigrafes, um problema de identidade: ele é o latino-americano que não se aceita, que nâo aceita a sua cultura, e tem no referente curopeu o seu modelo. Ele age, então, consoante uma lógica que foi desmontada pelo crítico cinematográfico Paulo Emílio Salles Gomes, a propósito de outro contexto, de que "a penosa construção de nós mesmos se desenvolve na dialética rarefeita entre o não-ser e o ser outro" . Logo, mais do que lógico que o ditador, que se quer ilustrado, eleja Paris como a sua cidade-modelo: "Ou se tinha uma grande capital ou não se tinha uma grande capital. E, apesar de tantas novidades, Paris continuaria sendo o Santo Lugar do bom gosto, do senso da medida, da ordem..." (1974, p. 22).

Essa fascinação pela capital francesa já tinha aparecido antes, na fiç̧ão de Carpentier, no Estêvão, de $O$ Século das Luzes, se bem que calcada em outros motivos: " Estêvão sonhava com Paris, as exposiçốes de pintura, os cafés intelectuais, a vida literária, queria fazer um curso naquele Colégio de França..." (1962, p. 29). Paris, como cidade-símbolo da ilustração, da urbanidade, aparecerá também nas últimas páginas de Concerto Barroco, representando uma opşão natural para o negro Filomeno, enquanto o $A$ mo retorna ao seu país, à sua cultura de origem. Paris será ainda um contraponto refinado, culto, para o outro narrador de $O$ Recurso do Método, ao descrever a passagem do Primeiro Magistrado pela mais cosmopolita cidade dos Estados Unidos: "Agora, o espetáculo das galerias e corredores suscitou ao Primeiro Magistrado algumas divertidas e agudas observaçōes sobre a artificialidade da aristocracia nova-iorquina, em comportamentos e trajes, quando era comparada com a de Paris" (pp. 36-7).

II

" $\Lambda$ artificialidade da aristocracia nova-iorquina" . Artificialidade. Essa palavra é essencial à economia narrativa de O Recurso.... para não dizer da maioria da fiç̧ăo de Carpentier. O artificial resulta do choque cultural, da adoçẫo de algo extremamente distante à cultura da terra de origem do personagem $\mathrm{c}$ pela acentuada ostentação de algo que não se adequa a um determinado sujeito. A questâo do artificial. 
do exotico, denunciará o sujeito cindido, a grotesca superposiçāo: " Embora certos sobrenomes de velha ascendência holandesa ou britânica remontassem ao século XVII, adquiriam, ao soar nas imediaçồes do Central Park, um não sei que de produto importado - ao mesmo tempo postiço e exótico..." ; " ...e outras formulas gastas, que só eram levadas a sério nesta América imitadora e atrasada..." ; " ...uns índios nossos, cultivadores de sisal, mas disfarçados de peles-vermelhas norte-americanos, porque haviam visto filmes da Vitagraph..." (pp. 37, 150 e 192).

Esse deslocamento, que ressalta a artificialidade das soluçóes dos imitadores, já havia sido colocado, em $O$ Século das Luzes, um romance, por sinal, emblemático dos transplantes culturais - no caso, a importação da Revolução Francesa pelo Caribe: "...nos engenhos de açúcar ou naquelas fazendas de Artemis, onde os ricos fazendeiros rivalizavam em pôr estátuas mitológicas à beira das plantações de fumo..." ; " ...rodeada de palmeiras e cafezais, a casa dos parentes de Jorge era uma espécie de palácio romano, cujas altas colunas dóricas se alinhavam ao longo de galerias exteriores enfeitadas com pratos de porcelana, vasos antigos, mosaicos de Talavera..." (pp. 36 e 279). No entanto, em outro romance - A Sagração da Primavera -, o choque pela implantação do estrangeiro (a difusão da cultura clássica) será mostrado como algo positivo, uma vez que cle se dá no contexto de um processo de educação, por Enrique, um intelectual, regressando a Havana, vindo da Europa, uma clara referência autobiografica de Carpentier: "E era maravilhoso ver os personagens de f́squilo entre colunas clássicas com palmeiras como fundo..." (1978, p. 217).

Assim, a incorporaçâo do estrangciro (seja cultural, político ou econômico) será vista quase sempre contraditoriamente nos romances de Carpentier. O Henri Christophe, de O Reino deste Mundo (1919), fará tudo para dar à sua corte um aspecto europeu ("E para cúmulo do luxo, um teatro de drama e ópera tinha sido inaugurado na Rua Vandreuil" (p. 35), enquanto os periféricos dos engenhos de açúcar de Cuba, no boom econômico da Primeira Guerra Mundial, cm Écue-Yamba-O (1933), rechaçarão a invasĩo americana (" Por acaso, um negro valia menos do que um americano?" , p. 57) da mesma forma que o Primeiro Magistrado, após o fuzilamento de um conspirador, o general Ataúlfo Galván, repelirá a "colaboração" de tropas norte-americanas: "Chegam vestidos de cáqui e saem cobertos de ouro" (p. 67). Já o etnomusicólogo de Os Passos Perdidos, ao localizar, em viagem pela sclva amazônica, uma comunidade que recitava um clássico medieval, constatará entusiasmado que, para aquele povo, "era mais interessante conservar a memória da Canção de Rolando que ter água quente a domicílio" (1953, p. 117).

A um deslumbramento pela cultura estrangeira - no caso dos personagens carpentieranos, a européia - corresponderá, na maioria dos casos, um desprezo por tudo o que diga respeito à sua origem, como no caso do Primeiro Magistrado, antes da definitiva volta a Paris, bem traduzido também pelas palavras do co-narrador: " ...com uma América de baixo cujas enseadas, escolhos e praionas conhecia táo bem quanto os mais experimentados goleteiros locais..." (p. 36); " ...na América Latina com artilharia, metralla e toda essa parafernália comprada dos ianques, a natureza nos mantém lutando ainda como nos tempos das Guerras Púnicas..." (p. 57); " ...um povo inculto que se negava a receber instrução pública que the era oferecida, povo fanatizado por práticas de bruxaria, incriveis superstições..." (p. 90); " ...nada do que acontecia lá, na pátria, importava para cla, pois resolvera, há muito tempo, viver para sempre na Europa, longe - dizia ela - desse país de sujeira e cheiro de sovaco" (p. 110).

O Primeiro Magistrado e o seu co-narrador opōem à "América de baixo" a Europa, mas é bom se destacar que, na Europa da maioria dos personagens de Carpentier, não cabe a Península lbérica, justamente de onde vieram os nossos descobridores-colonizadores. Diz o crudito llustre Acadêmico, guru intelectual do Primeiro Magistrado: "L Afrique commence aux Pyrénées. Nós havíamos recebido esse sangue nas veias; cra uma fatalidade. A gente de lá não cra como a de cá embora, e verdade, não carecesse de alguma qualidade, porque, enfim, Cervantes, El Greco..." (p. 91). A Espanha é vista pejorativamente também pelos revolucionários de O Século das Luzes: "I fazia-se um constante recontar de Bourbons cornudos, de rainhas licenciosas, de infantes cretinos, atribuindo-se o atraso da Espanha a um quadro sombrio de monjas chagadas, milagrarias e farrapos, perseguiçóes e atropelos, que lançava tudo o que existia entre os Pirincus e Ceuta nas trevas de uma godaria rediviva" (p. 103).

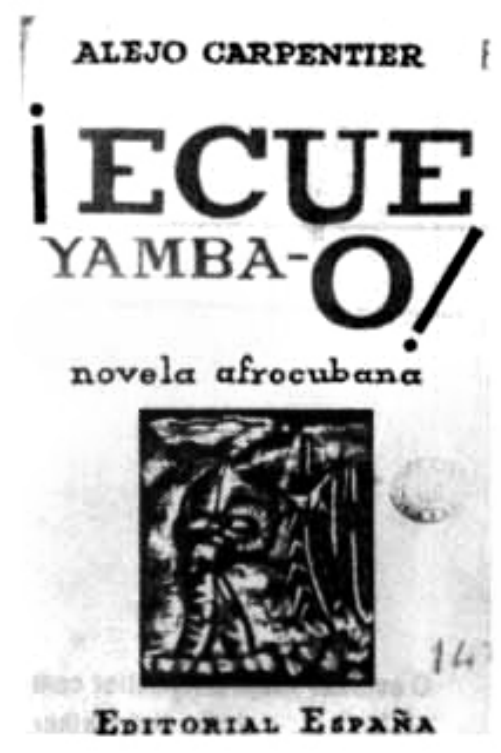

Capa de I Ecue Yamba-O!, do cubano Alejo Carpentier; nas outras páginas, ilustraçóes do livro com "firmas", ou simbolos de poténcias fiánigas 
A depreciação no romance carpentierano para com tudo o que leva a chancela da Espanha atinge, em Concerto Barroco, um dos seus momentos mais contundentes, mais sarcásticos, durante a arrumação das malas do Amo de partida para Veneza: " ...sofredora chorosa (...) atriz (...), pedindo vinho melhor do que este, entre choros e beijos, pois aquele de garrafa que agora tomavam, mesmo se dizendo vinho da Espanha, era vinho com borra (...), vinho bom para lavar aquilo..." (p. 12). É claro que todo esse ranço anti-hispânico tem a origem histórica no próprio processo de colonização, destruidor das culturas maia, inca e asteca. Processo lembrado pelo médico da Vila de Nossa Senhora da Assunção de Baracoa à bailarina Vera, de $A$ Sagração da Primavera. "Ambos, o herói civil e o herói militar, morreriam para conseguir a mesma independência... Mas, se graças a cles deixamos de ser colônia espanhola, pela má inspiração de outros, caímos na orbita dos Estados Unidos (...). Saímos do Círculo Ibérico, mas foi para cair numa roleta made in USA" (p. 418).

\section{III}

A presença do vizinho Estados Unidos é uma ameaça constante ao governo ditatorial do Primeiro Magistrado, mas não quando, por interesse em comprar em Washington armamento, munição e balōes-sonda, negocia a fatura em troca da cessão, para a United Fruit, a zona bananeira do Pacífico, uma atitude elogiada pelo

O escritor Alejo Carpentier com Lilia, sua mulher

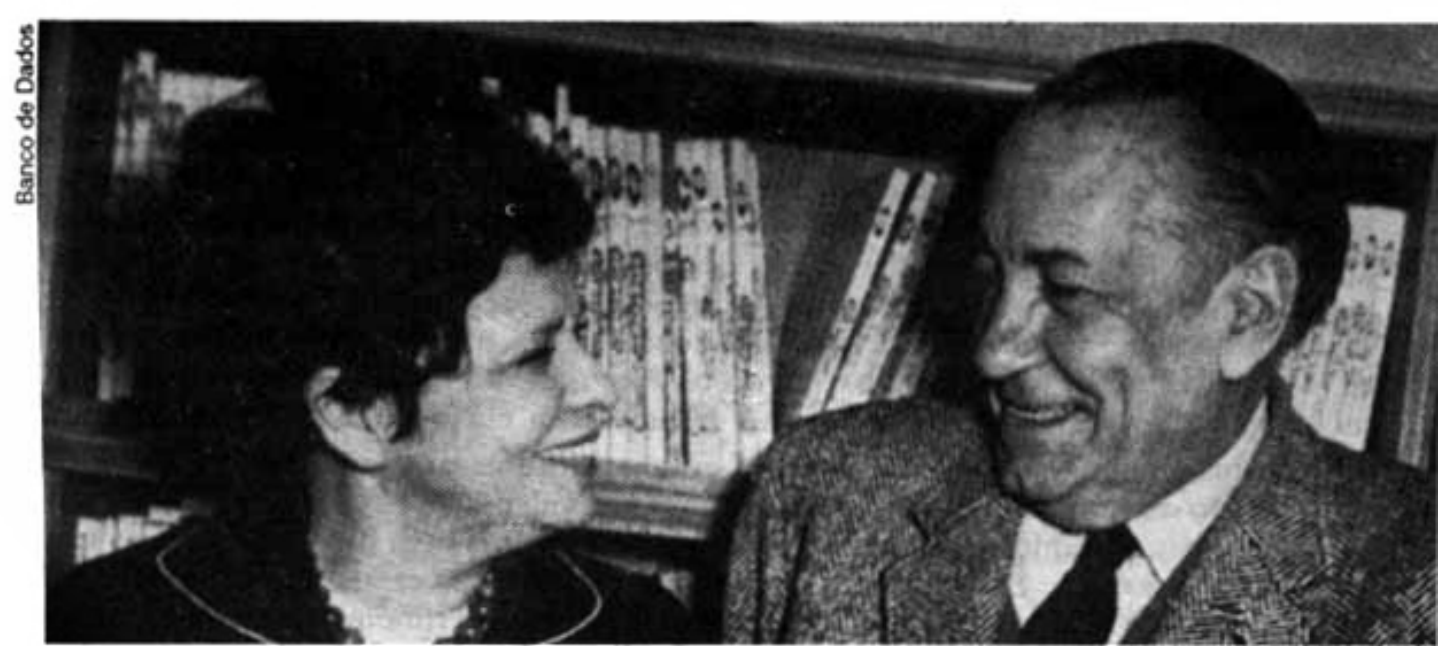

co-narrador: "...operaçāo que se arrastava há muito tempo por causa dos senôes, alegados e objeçōes de catedráticos e intelectuais, que só sabiam dizer besteiras, denunciando os apetites - inevitáveis, meu Deus, inevitáveis, fatais, queiramos ou năo, por razōes geográficas, por imperativos historicos - do imperialismo ianque" (p. 30). A compra das armas foi feita sob o impacto da rebelião do general Ataúlfo Galván ("Viva a Constituição. Viva a legalidade"). Os americanos voltarâo a estar próximos do PM quando toma corpo um movimento para substituir o "ilustrado" ditador pelo Doutor Luis Leoncio Martinez (" austero professor de filosofia, tradutor de Plotino"). O embaixador dos Estados Unidos chega ao acampamento: "Além do mais, era preciso acabar com as místicas socializantes do Doutor Luis Leoncio Martínez. Não íamos tolerar a ascensão de um segundo Madera nesta América de baixo. Se o país não regressasse prontamente a um regime de calma e respeito às propriedades estrangeiras, a intervençâo norte-americana seria inevitável" (p. 70).

Conseqüência da crise, o PM propōe que se faça um plebiscito para se votar sobre a sua permanência ou não no pođer, mas $40 \%$ da população sẫo constituídos de analfabetos e as ameaças de demissão $\mathrm{cm}$ massa, por parte das maiores empresas minciras, bananeiras e manufatureiras - apoiando o Presidente -, resultam na vitória nas urnas - fraudadas - do Primeiro Magistrado. Os Estados Unidos vão se infiltrando fortemente em lá, fazendo acordos, participando de negociatas (como a da United Fruit), mas o Primeiro Magistrado ainda vive voltado para uma certa Eu- 
ropa: "Paris, em troca, era Terra de Maravilhas e Terra de Promissão, Santo Lugar da Inteligência, Metrópole do Saber Viver, Fonte de Toda Cultura (...). Quando estivesse cansado das agitaçōes e multidōes de la, se retiraria, para esperar a morte, a esta casa que, a cada viagem, se fazia mais grata" (p. 88).

Na verdade, a "gratidão" parisiense estava somente na cabeça do Primeiro Magistrado, pois o jornal Le Matin havia publicado uma série de reportagens sobre as suas atrocidades lá, chamando-o de "Carniceiro de Nova Córdova". Assim, o PM, que se maravilhava com a liberdade de imprensa na França ("o imprecatório editorial de León Daudet, cujas geniais apocalípticas injúrias - expressão suprema da liberdade de imprensa - promoveriam duelos, seqüestros, assassinatos e tiroteios quotidianos nos nossos países", p. 10), acaba por comprar páginas nos jornais franceses, que chegavam até lá, para que o seu preceptor (intelectual) e servo (econô. mico) escreva matérias falsas sobre as relaçôes entre o PM e o povo de lá.

IV

Em um ensaio sobre a figura do ditador na fiç̧̃o hispano-americana, a partir de Facundo, de Sarmiento, Jaime Alazraki (1990) traça um paralelo entre o culto a cultura européia e o regime de terror, mostrando como, no caso do romance $O$ Recurso do Método, o Primeiro Magistrado manipula com a fórmula "civilização e barbárie", entendendo-se, obviamente, civilização como sinônimo de Europa, e barbárie, de América Latina. Assim, a superestimaçảo do Velho Mundo é a negação da América Latina. Negar a América Latina é justificar o abuso de poder. Dentro dessa "lógica" é que se pode entender que o homem que se diz cristão ("A Divina Pastora de Nova Córdova, Amparo Milagroso da minha pátria..."), apreciador das BelasArtes ("Um quarto de volta sobre mim mesmo e contemplo a fina marinha de Elstir...", p. 14), e da música clíssica ("grande apreciador de óperas"), amigo de finos escritores e um "Cruzado da Latinidade", patrocine uma seqüencia do real horroroso americano, como a ocorrida no Matadouro Municipal após uma insurreição.

No Matadouro Municipal: "E os últimos combatentes - uns trinta ou quarenta - foram levados ao Matadouro Municipal, onde, entre couros de reses, tripas, vísceras e fel de animais, sobre charcos de sangue coagulado, foram pendurados nos ganchos pelas axilas, pelos joelhos, pelas costelas ou pelo queixo, depois de feridos a pontapés e coronhadas. ' - Quem quer carne no espeto? Quem quer carne no espeto?' - gritavam os carrascos, arremedando os pregoeiros, dando outro golpe de baioneta num agonizante (...). Dos postes de telégrafo, dos álamos do parque, dos balcóes da Municipalidade, pendiam cachos de enforcados" (p. 76).

A associação Sarmiento-Carpentier, feita por Alazraki, ganha força quando se sabe que, em Nova York, de passagem para lá, o Primeiro Magistrado adquire uma "preciosíssima edição do Facundo. "... que the fez emitir amargos conceitos sobre o dramático destino dos povos latino-americanos, sempre empenhados num combate maniqueísta entre a civilização e a barbárie, entre o progresso e o caudiIhismo..." (p. 39). Três anos antes de publicar O Recurso do Método, Carpentier, em conferência em Genebra, falaria da sua dívida para com Sarmiento: "Aqui, a função social do escritor cumpre-se em funçāo da denúncia, mostrando perigos, que, mais tarde, irảo confirmar-se $\mathrm{cm}$ tremendas realidades. (Oh! Quem foi Suetonio de Rosas, o Doutor Francia, Melgarejo, Estrada Cabrera, Juan Vicente Gómez, Machado, Batista!...)" (1984, p. 19).

Se a Europa, para o Primeiro Magistrado, era a terra do Discurso do Método ("É verdade: não crescem plantas carnívoras, não voam tucanos, nem cabem ciclones

Descartes quem simboliza

a cultura européia

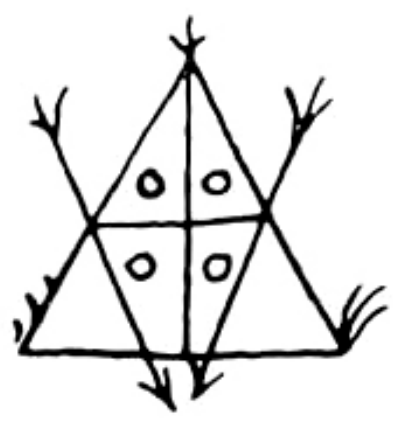




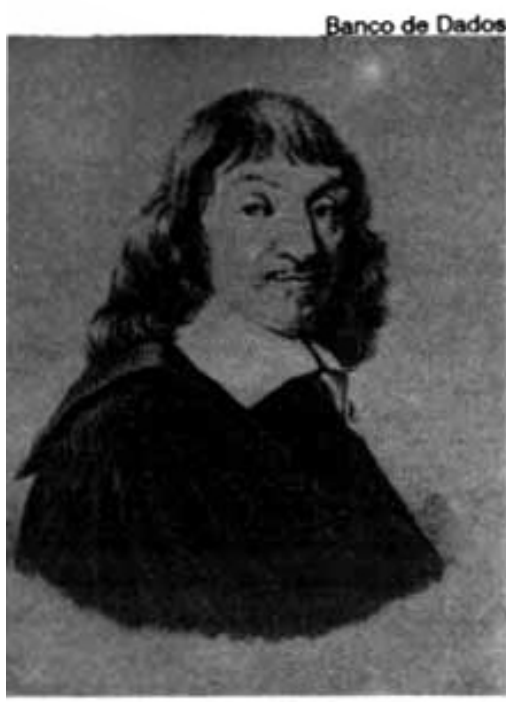

0 filósolo trancés René Descartes, 1596-1650 em O Discurso do Método", p. 19) e o lá a terra do recurso do método (" 'Fogo' . Nẩo havia outro jeito. Era a regra do jogo. Recurso do Método", p. 112), Peralta, em conversa na casa do Ilustre Acadêmico, irá mostrá-lo e ao PM que, na Europa, também, de vez em quando, partia-se para o recurso do método tâo apreciado pelo ditador: " ...e com exaltada irreverência fez desfilar diante dos olhos assombrados do llustre Acadêmico, como cristais de uma lanterna mágica, os crimes (...) o Terror Branco depois de Termidor..." (p. 91).

A narrativa de Peralta detém-se com minúcias na Revolução Francesa, tema caro a Carpentier: "...e sobretudo, sobretudo, por um hábil manejo de analogias, os dias da Comuna. Ali, os homens mais inteligentes e mais civilizados do mundo não tinham vacilado, vencida a resistência revolucionária, em exterminar a mais de dezes. sete mil homens" (p. 91). O Ilustre Acadêmico concorda que tudo é " tristement vraf" , mas tenta minorar todo aquele horror, desfilando nomes que a França teria dado ao mundo, como Descartes, Montaigne, Molière, Rousseau, Pasteur... O Presidente tenta a tréplica, mas lembra-se de algo fundamental: "... mas pensou que os nomes citados cairiam no vazio de uma cultura, que os ignorava" (p.92). Mais uma vez, o modelo desconhecia o modelado.

$\mathbf{V}$

A Revolução Francesa é uma das poucas referências explícitas a um fato histórico no romance $O$ Recurso do Método. Nessa obra, repleta de um bom humor, Carpentier procede diferentemente de quase todos os seus outros textos de fiç̧ăo, sempre precisos na localização de espaço (Cuba, São Domingos, Haiti, Espanha, Itália...) e de (re)composição de personagens. Sintomaticamente, o país latino-americano onde se dá um dos pólos do romance (o outro é a França) é identificado tão-somente com um advérbio de lugar - la -, e o seu personagem principal não e mais um verbete de enciclopédia, como Victor Hugues, Mackandal, Henri Christophe ou Cristóvão Colombo, mas sim um personagem, que é um composto de dita. dores reais: Salazar, Franco, Batista, Machado, Somoza, Trujillo, Gusmán Blanco, Cipriano Castro, Estrada Cabrera, Juan Vicente Gomez e Porfirio Díaz, como apontam Francisco J. D. de Castro e Maria P. Grau (1988, p. 122), a partir de um depoimento do proprio Carpentier.

Assim, de posse de um personagem principal totalmente construido, bastante artificial - palavra-chave no romance - Carpentier sentiu-se a vontade para o humor, o escracho. Castro e Grau alertam ainda para o fato de que o Primeiro Magistrado, melômano, afrancesado - Carpentier morou, ao todo, mais de dez anos em Paris - , dividindo a sua vida entre a América Latina e a França, é um retrato do próprio autor cubano. Independente do humor e do artificialismo exacerbado, $O$ Recurso do Métodoé um romance histórico, aliás como todos os outros títulos carpentieranos. Analisando o conceito de Historia que há no romance de Carpentier, Julio Rodrígues Puértolas (1988, p. 90) nota, dando como exemplos O Reino deste Mundo e O Século das Luzes, que, neles, pareceria como se a História se repetisse ciclicamente. Nesta linha de argumentaçăo, em que "a serpente morde o proprio rabo", todo o esforço revolucionário seria inútil, uma vez que tudo acaba de um jeito que dará nascimento a um novo ciclo, supostamente igual e destinado ao fra. casso. A Historia evoluindo circularmente, mas como uma espiral.

A idéia de fracasso histórico também passa pelas reflexōes do Primeiro Magistrado cóm relaçâo ao continente em que la está situado " ...barril de polvora de sempre, que muito me fazem lembrar, por isso, as nossas províncias andinas" (p.10); "...que, para o meu país, depois de um século de confusōes e quarteladas, havia-se encerrado o ciclo das revoluçóes" (p. 23); "O homem (...) rebelava-se assim à boliviana, fazendo ressurgir as rebeliôezinhas de uma época já superada..." (p. 28): "Dos cinqüenta e três pronunciamentos acontecidos num século de historia, mais de quarenta haviam sido promovidos por caudilhos do norte" (p. 42): " ...o Primeiro Magistrado via-se como que encerrado num círculo mágico, traçado pela espada de um Príncipe das Trevas. A História, que era sua, uma vez que nela desempenhava um papel, mordia o próprio rabo, engolia a si mesma, imobilizava-se em cada momento - pouco importando que as folhas dos calendários ostentassem um 185(?), 189(?), 190(?), 190(6?)..." (p. 118).

A visăo da História como uma sucessão de ciclos tem uma longa origem. Por um lado, o ocidental, tem uma fonte nas Quatro Idades da mitologia grega (Idade de 
Ouro, Idade de Prata, Idade de Bronze e Idade de Ferro). Pelo outro, o oriental, há o Círculo Hindu dos Quatro Yugas (Hrita, Treta, Dvapara e Kali). As Quatro Idades vão dar na concepçăo histórica de Giambattista Vico, "História Ideal Eterna", que consiste na repetição imutável das Três Idades - a Divina, a Herbica e a Humana - . numa série também infindável de "cursos e recursos".

A Idade Divina caracterizava-se por uma "sabedoria poética", que dotava homens " néscios, insensatos e horriveis bestas" de um aguçado sentido e uma forte fantasia, mas destituídos de qualquer poder de reflexão. Como sentiam e fabulavam sobre poderes terriveis e punitivos nas forças naturais, tratavam de proteger-se contra os castigos delas, domando os seus instintos, através do estabelecimento de famílias e a criação das primeiras " sociedades civis" . A Idade Heróica é marcada pela oligarquia como forma de governo, uma sociedade dividida entre patrícios e servos ou escravos, surgindo as cidades, governadas pela aristocracia. A reflexão ainda era sobrepujada pela fantasia.

A Idade Humana é a da democracia, resultado de uma luta pela igualdade de direitos por parte dos plebeus e é quando surge a filosofia platonica, procurando, no mundo das idéias, um acordo entre os interesses privados e o critério de uma justiça comum. Porém, nessa idade, por força do relaxamento dos laços tradicionais, com o questionamento dos valores e costumes, uma conseçüência da implantaçăo de repúblicas livres e democráticas, surgem a dissolução e a corrupção. Há intérpretes de Vico que acrescentam uma quarta fase - a Idade Cabtica - , marcada pelo individualismo e pela esterilidade, representando o ponto mais baixo na história do homem, terminando por um trovejar, que aterrorizaria a humanidade, redespertando-a, e principiando um novo ciclo com um retorno à Idade Divina.

Curiosamente, mas nảo gratuitamente, a idéia de um trovão para dar um fecho em um ciclo está claramente visualizada no capítulo "As Metamorfoses" de O Reino deste Mundo. "Um dia, daria o sinal para a grande revolta, e os Senhores do Além, tendo a frente Damballah, o Amo das Estradas e o Ogum das Armas, trariam o raio e o trovão para desencadear o ciclone que completaria a obra dos homens. Nesse grande momento - dizia Ti Noel - o sangue dos brancos correria pelos arroios, onde os Loas, ébrios de júbilo, iriam bebê- lo de bruços, até encher os pulmốes" (p. 23). Vale destacar ainda, com relação às "Idades", que, segundo Giambattista Vico, o homem cria os ciclos históricos, mas nảo domina as suas conseqüências e desdobramentos. Logo, a história humana assim somente adquiriria uma produção de sentido na sua relação com uma história ideal e eterna, o que, por sinal, está bem próximo à concepção de história que se tem no romance de Ti Noel e Mackandal.

Se, realmente, a concepção de Histórią, espelhada nos romances de Carpentier pelo menos em $O$ Reino deste Mundo e O Recurso do Método -, é cíclica, tem sentido, então, por exemplo, que, no início da $3^{3}$ parte de A Harpa e a Sombra, o narrador condene os "historiadores racionalistas", por serem eles "incapazes, talvez, de perceber uma poesia em atos, situada mais além de suas muralhas de documentos, crônicas e fichários". A "poesia em atos" é uma referência carpentierana clara à "técnica de ficção", desenvolvida por Arnold Toynbee, em seu A Study of History (1934-39), defendendo uma "forma de exposição poética".

Essa "forma de exposição poética" teria lugar quando a técnica histórica nâo tivesse condiçóes de ser precisa, como, por exemplo, ao se estudar períodos históricos de sessenta mil ou seis milhôes de anos. Segundo Toynbee, num período de, por exemplo, seis mil anos, através de um método de investigação comparativa, por meio da induçâo, é possível constatar-se a autenticidade de um relato, mas, com períodos mais longos, não seria mais possível uma técnica científica, racionalista. Ernst Robert Curtius, o conhecido autor de Literatura Européta e Idade Média

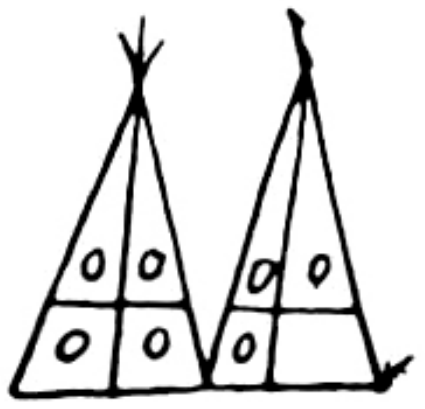


Latina, chega a defender enfaticamente a forma poética como o modelo perfeito para o historiador.

Ainda a respeito dos "historiadores racionalistas", a que se refere o narrador de A Harpa e a Sombra, e da clara identificação de Carpentier à visão histórica de Vico, é bom se atentar para a oposição que se estabelece entre as concepções históricas do autor de Principtos de (uma)Ciencia Nova e as do autor de Discurso sobre o Método. "A Historia foi posta pelo cartesianismo como um aglomerado confuso de fatos, uma miscelânea de absurdos, algo totalmente inapto à apreensão de idéias claras e distintas, as quais constituiriam a base de um verdadeiro conhecimento. Para Vico, esse desprezo é infundado e tem raizes no erro de admitir um único método como válido para todos os domínios da investigação, além disso, a História pode proporcionar esclarecimentos decisivos sobre aquilo que subjaz a própria ciência natural e que constitui o conhecimento humano" (Bosi, 1979, pp. XVII-VIII).

Se a concepção histórica trabalhada por Carpentier nos romances $O$ Retno deste Mundoe O Recurso do Método tem filiação no pensamento de Vico, que se opõe em termos ao de Descartes, o fato é que para o Primeiro Magistrado e para o seu co-narrador $E$ Descartes que simboliza a cultura européia, tanto que ambos associam a vitória da França contra a Alemanha, na Batalha do Marne, como "o triunfo da latinidade sobre o espírito germânico (...) havia sido a vitória de Descartes" (p.114). A partir desse episodio, haverá uma crescente associação do conceito de latinidade com a cultura do povo e do continente de lá. "Afinal de contas, latinidade não significava 'pureza de sangue', nem 'limpeza de sangue', como se costumava dizer em antiquados termos de Santo Ofício" (p. 116).

VI

O conceito de latinidade, como utilizado na ficção de Carpentier, vai servir claramente aos propósitos do Primeiro Magistrado em incorporar o povo de la na civilização de câ, a partir de sua associação com o uso do conceito de mestiçagem: " Dizer latinidade era dizer mestiçagem, e todos éramos mestiços na América Latina. Todos tínhamos algo de negro e de índio, de fenício ou mouro, de gaditano ou de celtíbero (...) Éramos mestiços com muita honra" (p. 116). Mestiçagem que é vista positivamente também, em Os Passos Perdidos, pelo jovem arquiteto, ex-estagiário de Le Corbusier, Jean-Claude: "Atrís de um bar, cheirando ao melhor rum, rodeados de gente que dançaria até depois do amanhecer, me esperavam todos os Ancestrais de um mundo - mundo nascido da mescla de dois mundos - que, por falta de melhor definiçăo, eu via como um mundo terceiro, ou melhor: um Terceiro Mundo, nascido de índios, negros e espanhois" (p. 74).

A questão da mestiçagem atravessa quase toda a obra ficcional de Alejo Carpentier: traduzindo um pensamento desse autor de que "esta terra americana foi o teatro do mais sensacional encontro étnico registrado nos anais do planeta: encontro do índio, do negro, e do europeu de tez mais ou menos clara, destinados, no futuro, a misturar-se, entremisturar-se..." (1984, p. 36). Essas palavras, parte de uma Aula Inaugural na Universidade Central da Venezuela, em 15 de maio de 1975. podem ser localizadas ao longo de muitas obras com uma redação mais ou menos similar.

Quando o co-narrador de $O$ Recurso do Método, a propósito da questấo do " Triunfo da Latinidade" , diz que "todas as raças do mundo antigo tinham-se amalgamado na prodigiosa bacia mediterrânea, mãe da nossa cultura" (p. 116), acaba por nos dar uma pista das origens do conceito de mestiçagem com que trabalha o romancista Carpentier. Segundo Irlemar Chiampi, " em todos os ideologemas do discurso americanista (...) considera-se que a parte ibérica do continente europeu representa, nos tempos modernos, a revivescência de um fenômeno, que marcou a história dos grandes centros europes, como a Mesopotámia, Grécia, Roma ou Espanha, onde o encontro de povos provocou a mistura de suas crenças, línguas, visões e técnicas, resultando em novas acomodações e formas originais de cultura" (1980, pp. 126-7).

É claro que esse discurso americanista surge sob o impulso revigorante de um texto de T. Spengler - A Decadência do Ocidente -, que problematiza o papel centralizador da cultura européia, concebendo a cultura como um organismo biologico. Nessa linha de argumentação, quando os mitos são substituidos pela reflexão 
de base filosófica, e o racionalismo pragmático e cético toma o lugar da mística religiosa, está próxima a decadência. Assim, a $\Lambda$ mérica, do ponto de vista de sua situação social, como um " universo-história", estaria em plena Primavera, anterior ao Outono da era reflexiva. Spengler, a exemplo de Vico, tambem era um defensor dos ciclos históricos com a História evoluindo do nascimento al maturidade e da decadência a morte e se propunha a criar as bases de uma "morfologia da História Universal".

No caso do romance em destaque - O Recurso do Método -, a entrada em cena da mestiçagem já é um sinal da conversão à causa da América Latina do europeizante Primeiro Magistrado. Um primeiro, nesse sentido da sua lenta conversão, havia sido dado ainda no $1^{\circ}$ capítulo, quando o PM contempla a beleza de sua filha, Ofélia: "A verdade $e$ que com essa cútis morena de india avançada, minha filha estava bela. Em nada havia herdado a redondez da cara, a grossura das coxas, a largura de cadeiras de sua santa mãe (...). Era mulher de pernas longas, seios pequenos, corpo esbelto - nova raça que estava nascendo por lá..." (p. 24). Esta mestiçagem racial far-se-á acompanhar, no raciocínio do PM, por um sincretismo cultural, fazendo com que a América Latina se insira então na cultura européia, na modernidade, na latinidade: "O importante era que, com isso, se afiançava, perante o conflito, que apavorava o mundo, nossa Consciência da Latinidade, porque tramos latinos, profundamente latinos, intimamente latinos, depositários da grande tradição que, através das Pandectas romanas, fundamento do nosso Direito, de Virgílio, de Dante, do Quixote, de Miguel Ângelo, Copérnico, etc..." (p. 128).

O sincretismo cultural - uma conseqüencia da mestiçagem - 6 um item importante no projeto literário de Alejo Carpentier $\mathrm{em}$ procurar uma identidade para a América Latina porque assim, um pouco antropofagicamente - ele nảo usa esse termo, tão caro a Oswald de Andrade - , construiremos a nossa cultura. Por isso, as manifestaçōes sincréticas serão vistas, na maioria das vezes, como algo positivo dizemos " na maioria das vezes" porque há textos de Carpentier, como ÉcueYamba- $O$, sem qualquer referência à mestiçagem -, como aparece em uma das passagens de $O$ Século das Luzes. "...os negros libertos reverenciavam seus velhos deuses da África, na figura das mesmas imagens que se erguiam nos altares dos templos católicos" (pp. 276-7). A mestiçagem, que corre em paralelo com o sincretismo, torna-se, entấo, o signo cultural da identidade americana, como aponta Irlemar Chiampi, no ensaio "A História Tecida pela Imagem" (1988, p. 18).

\section{VII}

O fato e que o Primeiro Magistrado, paulatinamente, vai-se afastando da sua idolatria incontestável a França - primeiro passo para a aceitação de lá. "Havia terminado o reino dos Gigantes: Hugo, Balzac, Renán, Michelet, Zola. Já não se produziam, aqui, espíritos dotados de tal universalidade e, por isso, a França começaria a pagar o grave pecado que era, neste século multiforme, uma orgulhosa subestimação de tudo aquilo que estivesse situado além de suas fronteiras" (p. 100). Essa reação dá-se num clima bastante passional (" E todo o mundo lhe dava as costas no único lugar do Universo onde a opinião alheia tinha ainda para ele algum valor", p. 93), mas o fato é que já se trata de uma primeira manifestaçăo de crítica à sua paixão. Em lá, a França já começara a ceder espaço aos Estados Unidos: "...uma cultura cujo eixo de gravitação - já era tempo de proclamá-lo - havia-se deslocado para a América do Norte..." (p. 198).

As coisas mudam para valer na terra do lá, começando por um grande processo insurrecional, que se acreditava comandado pelo Estudante, mas que $\epsilon$, na verdade, fruto de uma grande insatisfaçāo geral, manifestada em uma série de atos terroristas promovidos pelo proprio braço direito do PM, Peralta. Estilisticamente, é curioso como a figura do Estudante vai sendo construida por Carpentier como se fosse um mito, e o "desorganizar o organizado", em termos de técnica narrativa, é muito semelhante à construção do mito de Mackandal, de O Retno deste Mundo. À guisa de uma melhor ilustração do que se disse, vamos levantar, aleatoriamente, a seguir, alguns trechos de ambos os romances, destacando-se náo a coincidência no uso de vocábulos entre os dois textos, mas como, nos trechos emparelhados, há uma similaridade de conteúdo, traduzida formalmente numa preocupação de descrever o indescritivel, de captar o maravilhoso: 


\section{O REINO DESTE MUNDO}

"O que mais assombrou $\mathrm{Ti}$ Noel foi a evidência de um longo e paciente trabalho realizado pelo mandinga desde a noite de sua fuga. Dir-se-ia que tinha percorrido todas as fazendas da Planície, uma a uma, tratando diretamente com todos os que nela trabalhavam" (p. 14).

"O veneno se espalhou pela Planicie do Norte, invadindo os potreiros e os estábulos. Não se sabia como se introduzira entre as gramas e as alfafas, entre os fardos de forragem, e nem como alcançava as mangedouras" (p. 17).

" Todos sabiam que o lagarto verde, a mariposa noturna, o cachorro desconhecido e o incrivel pelicano não seriam senão sim. ples disfarces" (p. 22).

"...um homem ungido pelos grandes Loas" (p. 30).

\section{O RECURSO DO MÉTODO}

" Dizia-se que o Estudante esse ' estudante' que estava começando a ser muito falado - sempre ativo embora invisível, transferindo-se da Planície para a Montanha, dos portos pesqueiros para as serrarias das Terras Quentes, era $o$ instigador, o organizador de tudo aquilo" (p. 207).

" Era todo um exército escondido, móvel, inteligente, cheio de idéias e de perfídia esse que agora agia $\mathrm{cm}$ toda parte para desorganizar o organizado, desarticular os mecanismos administrativos, manter as autoridades $\mathrm{em}$ perene sobressalto e, sobretudo, manter um crescente clima de alarme" (p. 212).

"I: a lenda do Estudante se enriquecia com laudatórios acontecimentos, noticiários e romances que corriam de boca em boca: dizia-se que deslizava por janelas tăo estreitas que sua passagem era coisa de portento" (p. 213).

"...ele está se transformando num mito..." (p. 213).

"Não quero mitos. Nada caminha tanto neste continente como um mito" (p. 214), observa muito propriamente o Primeiro Magistrado a propósito das histórias do Estudante. À observação do Mandatário, Peralta desfila um rol de mitos presentes na história americana, como a confirmar as palavras do chefe: Inca Paracleto, Mackandal, Mito da Ressurreição-dos-Antigos-Deuses, Mito de Um-HomemDe-Pele-Clara-que-viria-do-Oriente, Emiliano Zapata e - para ironizar com os únicos latino-americanos de lingua portuguesa - o Mito de Augusto Comte à brasileira. Fosse mais corajoso, poderia Peralta arrolar a esses mitos o nosso mais persistente: o Mito do Ditador.

É o ensaista Jaime Alazraki quem observa ser o ditador o único personagem mitologico realmente produzido pela América Latina: " Como Sarmiento, Márquez y para el caso todo novelista del dictador - idealiza su personaje, es decir, lo modela, partiendo de un personaje bistórico, según sus propias ideas, su propia visión de lo que el dictador es y no es. No se trataba de enbebrar un anecdotariode Rosas o de Gómez o de quien fuera -, sino de articular en un personaje una percepción mitológica. También en este sentido Márquez ba sido explictio: ' El tema del dictador ba sido una constante de la literatura latinoamericana desde sus origenes, y supongo que lo seguira siendo' " (p. 23).

Ainda estabelecendo paralelos entre $O$ Reino deste Mundo e $O$ Recurso do Método - mesmo número de palavras e de letras e as mesmas iniciais - , talvez fosse interessante observar que, em ambos, os personagens tomados como mitos dăo partida a um processo, que será finalizado por outras pessoas, coletivamente: " $\lambda$ sua mente retornavam confusas reminiscencias das coisas contadas pelo maneta Mackandal, há tantos anos, que não sabia dizer quando havia sido. Naqueles dias começava a ter a certeza de que tinha uma missão a cumprir..." ( $O$ Reino deste Mundo, p. 108). No caso de $O$ Recurso do Mútodo, o processo desencadeado pelo Estudante vai levar à posse do Doutor Luis Leoncio: " - Você tem que saber que, na verdade, foi o Estudante quem o derrubou - diz o enfermeiro" (p. 250). 
Desapeado finalmente do poder, o Primeiro Magistrado está de volta a Paris, cidade ideal para exílio de ditadores ("... esta alegria, esta civilização..." ), instalado na sua casa da Rue de Tilsitt - curiosamente, o nome de um romance de Guilherme de Figueiredo, irmão de outro ditador, João Batista de Oliveira Figueiredo - , chamando a si próprio de "O Ex". O primeiro choque é a decoração, enriquecida por peças cubistas, dadaístas e construtivistas, colocadas pela filha, que continua achando la um "país de selvagens". Ele se lamenta do fim de todos os ditadores latinoamericanos, continua dormindo de rede, constata a modernização da Cidade-Luz (" O cheiro de gasolina tinha substituido o olor agreste - antanho universal e sem fronteiras, tão da capital como da aldeia - da bosta de cavalo", p. 285), percebe o desajuste entre pensamento e lugar ("Tudo, menos to be or not to be $\mathrm{cm}$ casas de putas", p. 287) e delicia-se com a improvisada culinária de la, mesmo morando vizinho ao Arco do Triunfo: "Várias bandejas e pratos apresentavam, aí, como se estivessem dispostos num suntuoso armazém tropical" (p. 290).

O manjar, inicialmente rejeitado por Ofelia, terá nela um efeito surpreendente, e uma pamonha de milho verde evocará, pelo cheiro, lembranças da sua infância numa referência mais do que clara d " madeleine" , de Em Busca do Tempo Perdido, de Proust. Para que a referência a Proust não pareça absurda, é bom se reparar que o mesmo expediente da citaçâo ironizada é utilizado por Carpentier, dezesseis anos depois, no romance A Sagraçao da Primavera. " ... reconstruía toda sua infância, toda sua adolescência, somente por morder um pedaço de mandioca..." (p. 187). O título de um livro de Proust - À Sombra das Raparigas em Flor - e ainda citado com humor no mesmo $O$ Recurso do Método : "Encontrava repouso e sossego, finalmente, o Primeiro Magistrado, à sombra dos canhōes em for" (p. 135).

"Madeleines" à parte, o fato é que a casa do PM em Paris tropicaliza-se por decisiva influência da Maiorala, mulher de cama e mesa (em off) do " Ex" : "...E começaram a ser vividos, ali, sob teto de pedra, latitudes e horas que eram de outra parte e de outra época..." (p. 294), com o PM trocando a leitura de jornais franceses (Le Figaro, Le Journal, Le Petit Parisien) pelos de lá (O Mercurio, O Mundo, Últimas Notícias, O Farol, A Sentinela), onde lê o delirante discurso de posse do Doutor Luis Leoncio. Agora, o Primeiro Magistrado começa a inverter tudo, transferindo para o domicílio em Paris hábitos da terra de lá, desvencillhando-se do seu verniz europeizante. Na culinária, nas roupas e nos costumes, ele transportava a sua América, outrora, "imitadora e atrasada" para a sua casa dos últimos dias. O Primeiro Magistrado se aceitava enfim; aceitava a sua cultura de origem.

Depois de visitar o Cemitério de Montparnasse - onde estavam enterrados Porfirio Díaz e Baudelaire, dos seus ídolos - , o PM vai agonizando e morre num dia de domingo, sendo enterrado perto da tumba do poeta de Les Fleurs du Mal Para aquele que tinha vivido do jogo do artificial, do truque, da dissimulaçáo, enfim, nada mais justo que a "Terra do Sagrado Solo Pátrio", anunciada na lápide, seja apenas a de um canteiro do Jardim de Luxemburgo, em Paris. Nem morto, o Primeiro Magistrado se livrava do simulacro.

\section{BIBLIOGRAFIA}

AlAzraKI, Jaime. " Facundo, de Sarmiento, y la novela hispanoamericana", in Casa de las Americas La Ha. bana, Ano XXX, Número 180, mayo-junio/19\%0, pp. 14-28.

BOSI, Nffedo." Vico. Vida e Obra", in VICO, Giambattista. Principios de (uma)Ciéncia Noua Sıo Paubo, Abril Cultural, 1979. Traduça de Antonio Lixaro de Almeida Prado.

CARPENTIER, Nejo. Ecue-Yamba- $O$ S Sto Paulo, Brasiliense, 1988. Traduçao de Mustafa Yazbek.

O Reino deste Munda Rio de Janeiro, Civilizaço Brasilcira, 1985. Traduçáo de Josto Olavo Saldanha. Os Passos Perdidos Sto Paulo, Brasiliense, 1985. Traducto de Josely Vianna Baptista. O Cerco (El Acoso). Sto Paulo, Global, 1988. Traduçıo de Eliane Zagury.

O Sfeculo das Luzes Sto Paulo, Global, 1985. Traduço de Stella Leonardos.

O Recurso do Motodo Rio de janeiro, Marco Zero, 1985. Traduçao de Beatriz A. Cannabrava.

Coelho. Concerto Barroca Sto Paulo. Brasiliense, 1985. Traducto de Jean-Claude Bernardet e Teixeira

A Sagraçào da Primavera Sto Paulo, Brasiliense, 1987. Traduçăo de Mustafa Yazbek.

A Harpa e a Somibra Rio de Janeiro, Bertrand Brasil, 1987. Traduço de Reinaldo Guarany.

Molina.

A Literatura do Maraullboso. Sto Paulo, Vertice, 1987. Traduçto de Rubia Prates Goldoni e Sergjo

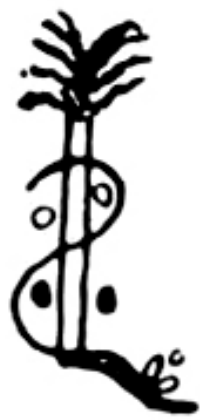

